Zeszyty Naukowe Szkoły Głównej Gospodarstwa Wiejskiego w Warszawie

Problemy Rolnictwa Światowego tom 18 (XXXIII), zeszyt 2, 2018: 183-192

DOI: 10.22630/PRS.2018.18.2.46

Karol Kukula $^{1}$, Lidia Luty ${ }^{2}$

Uniwersytet Rolniczy im. Hugona Kołłątaja w Krakowie

\title{
O wyborze metody porządkowania liniowego do oceny gospodarki odpadami w Polsce w ujęciu przestrzennym
}

\section{On the Selection of the Linear Ordering Method for the Evaluation of Waste Management in Poland in Spatial Approach}

\begin{abstract}
Synopsis. Celem artykułu jest przedstawienie techniki wyboru metody porządkowania liniowego obiektów ze względu na poziom zjawiska złożonego jakim jest stan gospodarki odpadami w województwach Polski. Do realizacji tego celu wyselekcjonowano cechy diagnostyczne opisujące badane zjawisko oraz wytypowano metody porządkowania liniowego. Następnie wykorzystując procedurę wyboru metody porządkowania dokonano wytypowania sposobu konstrukcji cechy syntetycznej, który pozwolił zbudować ranking województw ze względu na poziom analizowanego zjawiska. W dalszej kolejności dokonano podziału województw na cztery grupy: bardzo wysokiego, wysokiego, przeciętnego i niskiego poziomu rozwoju omawianego zjawiska. Badania pokazały, że wybór procedury konstrukcji cechy syntetycznej wpływa na ranking badanych obiektów. Otrzymany ranking pozwala sformułować wniosek, iż gospodarka odpadami w Polsce jest regionalnie zróżnicowana.
\end{abstract}

Słowa kluczowe: metoda porządkowania liniowego, cecha syntetyczna, odpady komunalne

\begin{abstract}
The aim of the article is to present the technique of selection of the method of the linear ordering of objects due to the level of a complex phenomenon, which is the status of waste management in voivodeships in Poland. For this purpose there were selected diagnostic variables describing the analyzed phenomenon and linear ordering methods were selected. Then, using the selection procedure for ordering methods, it was chosen the method of construction of a synthetic variable, that allowed to build ranking of voivodeships due to the level of the analyzed phenomenon. Then the voivodeships were divided into four groups: very high, high, average and low level of the discussed phenomenon. The research showed that the selection of procedure for the construction of synthetic variable affects the ranking of tested objects. The obtained ranking allows to conclude that waste management in Poland is regionally differentiated.
\end{abstract}

Key words: linear ordering method, synthetic variable, municipal waste

JEL Classification: $\mathrm{C} 10, \mathrm{R} 10$

\section{Wprowadzenie}

Rozwój gospodarczy niesie z sobą wiele pozytywów ale wywołuje także pewne ujemne skutki. Odpady powstające zarówno w gospodarstwach domowych - odpady komunalne jak i w przemyśle są źródłem trudnych do rozwiązania problemów m. in. ze

\footnotetext{
${ }^{1}$ prof. zw. dr hab., Katedra Statystyki i Ekonometrii, Wydział Rolniczo-Ekonomiczny, UR w Krakowie, al. Mickiewicza 21,31-120 Kraków, e-mail: ksm@ur.krakow.pl

${ }^{2} \mathrm{dr}$, Katedra Statystyki i Ekonometrii, Wydział Rolniczo-Ekonomiczny, UR w Krakowie, al. Mickiewicza 21,

31-120 Kraków, e-mail: rrdutka@cyf-kr.edu.pl; https://orcid.org/0000-0001-8250-8331
} 
względu na to, że są gromadzone na wysypiskach pozbawionych urządzeń do ich konwersji (Kukuła, 2017). Gospodarka odpadami, jest ważnym elementem biogospodarki, która pozwala zachować czystość środowiska naturalnego $\mathrm{w}$ połączeniu $\mathrm{z}$ wykorzystaniem surowców wtórnych, przynosząc tym samym korzyści ekonomiczne. Zarządzania w tej dziedzinie może mieć wielki wpływ na przebieg ekonomiczno-społecznych procesów (Adamowicz, 2014). W szczególności celem racjonalnej gospodarki odpadami komunalnymi jest popularyzacja selekcji odpadów u źródła ich powstawania, czyli w gospodarstwach domowych, a tym samym umożliwienie realizacji recyklingu.

Metody Wielowymiarowej Analizy Porównawczej (WAP) umożliwiają prowadzenie kompleksowych badań różnorodnych zjawisk złożonych ${ }^{3}$, stwarzając tym samym możliwości szerokiego i obiektywnego spojrzenia na te zjawiska. W szczególności zagadnienia społeczno-ekonomiczne posiadające wymiar przestrzenny są analizowane z wykorzystaniem metod WAP. W Polsce po raz pierwszy próbę opisu zjawisk złożonych za pomocą cechy syntetycznej podjął Hellwig (1968).

Niezwykle ważną czynnością $\mathrm{w}$ procesie budowy rankingu ze względu na poziom zjawiska złożonego jest dokonanie właściwego wyboru cech diagnostycznych, które wywierają wpływ na kolejność obiektów klasyfikowanych. W literaturze przedmiotu stawia się kilka postulatów wobec czynności kwalifikowania cech do zbioru cech diagnostycznych, w tym:

- kryterium merytoryczne - istotne charakteryzowanie ilościowych i jakościowych aspektów stanów badanych obiektów, czyli uwzględnienie: mierzalności cech, dostępności danych liczbowych, wiarygodności danych, ekonomiczności (koszt zebrania informacji), interpretowalności, a także charakteru cech,

- kryterium metodologiczne - charakteryzowanie się cech wysoką zmiennością w zbiorze badanych obiektów.

Wielu autorów, w tym m. in. Grabiński (1984) postuluje ponadto, że przyjęte cechy do budowy rankingu winny być słabo skorelowane między sobą. Założenie takie jest istotne w modelowaniu ekonometrycznym, a nie w procesie budowy rankingu obiektów w oparciu o ich oceny wielokryterialne, czyli uwzględniające pewną liczbę ważnych merytorycznie cech.

Kolejną bardzo ważną kwestią występujących przy budowie rankingu ze względu na poziom zjawiska złożonego jest wybór metody porządkowania. W szczególności w metodach porządkowania liniowego opartych na zmiennej syntetycznej ważnym etapem jest unormowanie cech diagnostycznych oraz sposób konstrukcji zmiennej syntetycznej. stycznych. W literaturze przedmiotu można znaleźć wiele oryginalnych pomysłów w tym zakresie: Perkal (1953); Hellwig (1968); Wesołowski (1975); Bartosiewicz (1976); Nowak (1977); Strahl (1978); Borys (1978); Hwang, Yoon (1981); Kukuła (1994, 2000); Lira, Wagner, Wysocki (2002); Pawełek (2008); Młodak (2006); Walesiak (2014); Kisielińska (2016). Wielu autorów prac empirycznych rozpoczynając swe badania, mające na celu budowę rankingu obiektów ze względu na ich oceny wielokryterialne, zmaga się $\mathrm{z}$ dylematem: którą z metod porządkowania liniowego wybrać?

Głównym celem pracy jest przedstawienie empirycznego wykorzystania procedury wspomagającej wybór jednej z wielu często stosowanych metod (Kukuła, Luty, 2015, 2017). Ponieważ zjawisko gospodarki odpadami komunalnymi jest złożonym zjawiskiem,

${ }^{3}$ Zjawiskiem złożonym nazywa się zjawisko, które jest opisywane zbiorem skończonej liczby cech $m>1$ (Strahl, 1978). 
stąd jego badanie jest możliwe przy użyciu metody związanej z wielowymiarową analizą porównawczą. W pracy stworzono ranking województw w 2015 roku ze względu na poziom gospodarowania odpadami, a następnie wyróżniono cztery grupy województw, które charakteryzują się odpowiednio: bardzo wysokim, wysokim, średnim oraz niskim poziom rozwoju badanego zjawiska.

\section{Dane i metody}

Analize gospodarki odpadami komunalnymi prowadzono na podstawie danych wtórnych Głównego Urzędu Statystycznego w Warszawie (tabela 1).

Tabela 1. Wartości cech diagnostycznych

Table 1 . The values of diagnostic variables

\begin{tabular}{|c|c|c|c|c|c|c|c|c|c|c|c|}
\hline \multirow[b]{2}{*}{ Województwo } & \multicolumn{11}{|c|}{ Cechy diagnostyczne } \\
\hline & $X_{1}$ & $X_{2}$ & $X_{3}$ & $X_{4}$ & $X_{5}$ & $X_{6}$ & $X_{7}$ & $X_{8}$ & $X_{9}$ & $X_{10}$ & $X_{11}$ \\
\hline dolnośląskie & 340 & 87 & 46 & 43 & 8,1 & 27 & 5 & 38,1 & 0,3 & 23,3 & 4,4 \\
\hline kujawsko-pomorskie & 284 & 70 & 47 & 25 & 3,1 & 18 & 8 & 0,0 & 1,7 & 16,9 & 5,6 \\
\hline lubelskie & 180 & 40 & 34 & 37 & 3,7 & 31 & 1 & 2,5 & 0,0 & 0,7 & 0,1 \\
\hline lubuskie & 328 & 88 & 43 & 21 & 5,3 & 10 & 3 & 1,5 & 0,0 & 7,0 & 1,2 \\
\hline łódzkie & 263 & 80 & 54 & 24 & 3,1 & 19 & 4 & 0,6 & 0,0 & 0,2 & 0,0 \\
\hline małopolskie & 236 & 52 & 32 & 67 & 2,8 & 19 & 6 & 3,5 & 70,0 & 55,2 & 13,5 \\
\hline mazowieckie & 311 & 84 & 31 & 71 & 6,3 & 31 & 16 & 10,0 & 124,7 & 151,6 & 34,1 \\
\hline opolskie & 279 & 77 & 38 & 18 & 1,7 & 18 & 3 & 5,8 & 0,0 & 8,5 & 0,4 \\
\hline podkarpackie & 196 & 37 & 37 & 42 & 2,8 & 14 & 2 & 0,0 & 11,7 & 4,7 & 2,5 \\
\hline podlaskie & 241 & 88 & 32 & 41 & 2,4 & 11 & 1 & 4,8 & 0,0 & 0,0 & 0,8 \\
\hline pomorskie & 305 & 82 & 61 & 34 & 4,9 & 13 & 9 & 9,8 & 2,7 & 16,3 & 4,0 \\
\hline śląskie & 332 & 102 & 64 & 5 & 5,2 & 24 & 14 & 12,0 & 0,0 & 1,2 & 2,1 \\
\hline świętokrzyskie & 166 & 40 & 18 & 10 & 3,6 & 12 & 1 & 0,0 & 0,0 & 0,8 & 0,4 \\
\hline warmińsko-mazurskie & 271 & 60 & 53 & 32 & 3,9 & 10 & 2 & 0,0 & 0,0 & 3,2 & 2,4 \\
\hline wielkopolskie & 308 & 94 & 57 & 28 & 6,1 & 33 & 7 & 0,0 & 0,0 & 1,5 & 0,7 \\
\hline zachodnio-pomorskie & 337 & 53 & 61 & 48 & 5,0 & 13 & 6 & 0,8 & 2,2 & 32,7 & 5,4 \\
\hline
\end{tabular}

Źródło: opracowanie własne na podstawie Ochrona Środowiska - Environment 2016, GUS.

Do analizy przyjęto następujące cechy diagnostyczne:

- odpady komunalne na 1 mieszkańca w kg:

$X_{1}$ - zebrane,

$X_{2}$ - przeznaczone do recyklingu,

$X_{3}$ - przeznaczone do kompostowania lub fermentacji,

$X_{4}$ - przeznaczone do konwersji technicznej,

$X_{5}$ - zebrane selektywnie z gospodarstw domowych;

- składowiska: 
$X_{6^{-}}$liczba składowisk kontrolowanych, na których składowane są odpady komunalne, wyposażone $w$ instalacje odgazowywania,

$X_{7}$ - liczba składowisk z instalacją gazową połączone z odzyskaniem energii cieplnej i elektrycznej,

$X_{8}$ - powierzchnia składowisk z odpadami komunalnymi o zakończonej eksploatacji

i rekultywowanymi w ha;

- odpady opakowaniowe na 1 mieszkańca w tys. kg:

$X_{9}$ - szkło poddane recyklingowi,

$X_{10}$ - papier i tektura poddane recyklingowi,

$X_{11}$ - plastiki i tworzywa sztuczne poddane recyklingowi.

Wybierając cechy diagnostyczne do opisu gospodarki odpadami komunalnymi kierowano się analizą: merytoryczną - biorącą pod uwagę znaczenie wskaźnika w ocenie zjawiska złożonego, statystyczną - odpowiedni poziom zmienności (współczynnik zmienności co najmniej 0,1 ; iloraz skrajnych wartości co najmniej 2) oraz dostępnością danych (tabela 1). Wszystkie cechy są stymulantami. Wartości charakterystyk liczbowych cech diagnostycznych przedstawiono $\mathrm{w}$ tabeli 2.

Tabela 2. Podstawowe charakterystyki przyjętych cech diagnostycznych

Table 2. The basic characteristics for selected diagnostic variables

\begin{tabular}{|c|c|c|c|c|c|c|c|c|c|c|c|}
\hline \multirow{2}{*}{$\begin{array}{c}\text { Charakterystyki } \\
\text { liczbowe }\end{array}$} & \multicolumn{11}{|c|}{ Cechy diagnostyczne } \\
\hline & $X_{1}$ & $X_{2}$ & $X_{3}$ & $X_{4}$ & $X_{5}$ & $X_{6}$ & $X_{7}$ & $X_{8}$ & $X_{9}$ & $X_{10}$ & $X_{11}$ \\
\hline $\max$ & 340,0 & 102,0 & 64,0 & 71,0 & 8,1 & 33,0 & 16,0 & 38,1 & 124,7 & 151,6 & 34,1 \\
\hline $\min$ & 166,0 & 37,0 & 18,0 & 5,0 & 1,7 & 10,0 & 1,0 & 0,0 & 0,0 & 0,05 & 0,04 \\
\hline średnia & 273,6 & 70,9 & 44,3 & 34,1 & 4,3 & 18,9 & 5,5 & 5,6 & 13,3 & 20,2 & 4,9 \\
\hline mediana & 281,5 & 78,5 & 44,5 & 33,0 & 3,8 & 18,0 & 4,5 & 2,0 & 0,0 & 5,8 & 2,3 \\
\hline $\begin{array}{l}\text { mediana } \\
\text { Webera }\end{array}$ & 280,8 & 73,6 & 47,2 & 28,6 & 3,7 & 17,6 & 5,4 & 3,8 & 4,0 & 12,3 & 3,3 \\
\hline $\begin{array}{l}\text { odchylenie } \\
\text { standardowe }\end{array}$ & 54,5 & 20,3 & 12,9 & 17,5 & 1,6 & 7,7 & 4,4 & 9,3 & 33,3 & 36,9 & 8,2 \\
\hline $\begin{array}{l}\text { współczynnik } \\
\text { zmienności }\end{array}$ & 0,2 & 0,3 & 0,3 & 0,5 & 0,4 & 0,4 & 0,8 & 1,7 & 2,5 & 1,8 & 1,7 \\
\hline $\max / \min$ & 2,0 & 2,8 & 3,6 & 14,2 & 4,7 & 3,3 & 16,0 & - & - & 3053,7 & 967,6 \\
\hline
\end{tabular}

Źródło: opracowanie własne na podstawie tabeli 1.

Zauważymy, że cechy $X_{7}-X_{11}$ w badanej grupie obiektów charakteryzuje bardzo duże zróżnicowanie o czym świadczą wartości miar zróżnicowań. Wpływa to także na różnice między średnimi i medianami tych cech.

W pierwszym etapie badań wytypowano siedem procedur porządkowania liniowego (tabela 3). 
Tabela 3. Wybrane metody porządkowania liniowego

Table 3. Chosen linear ordering methods

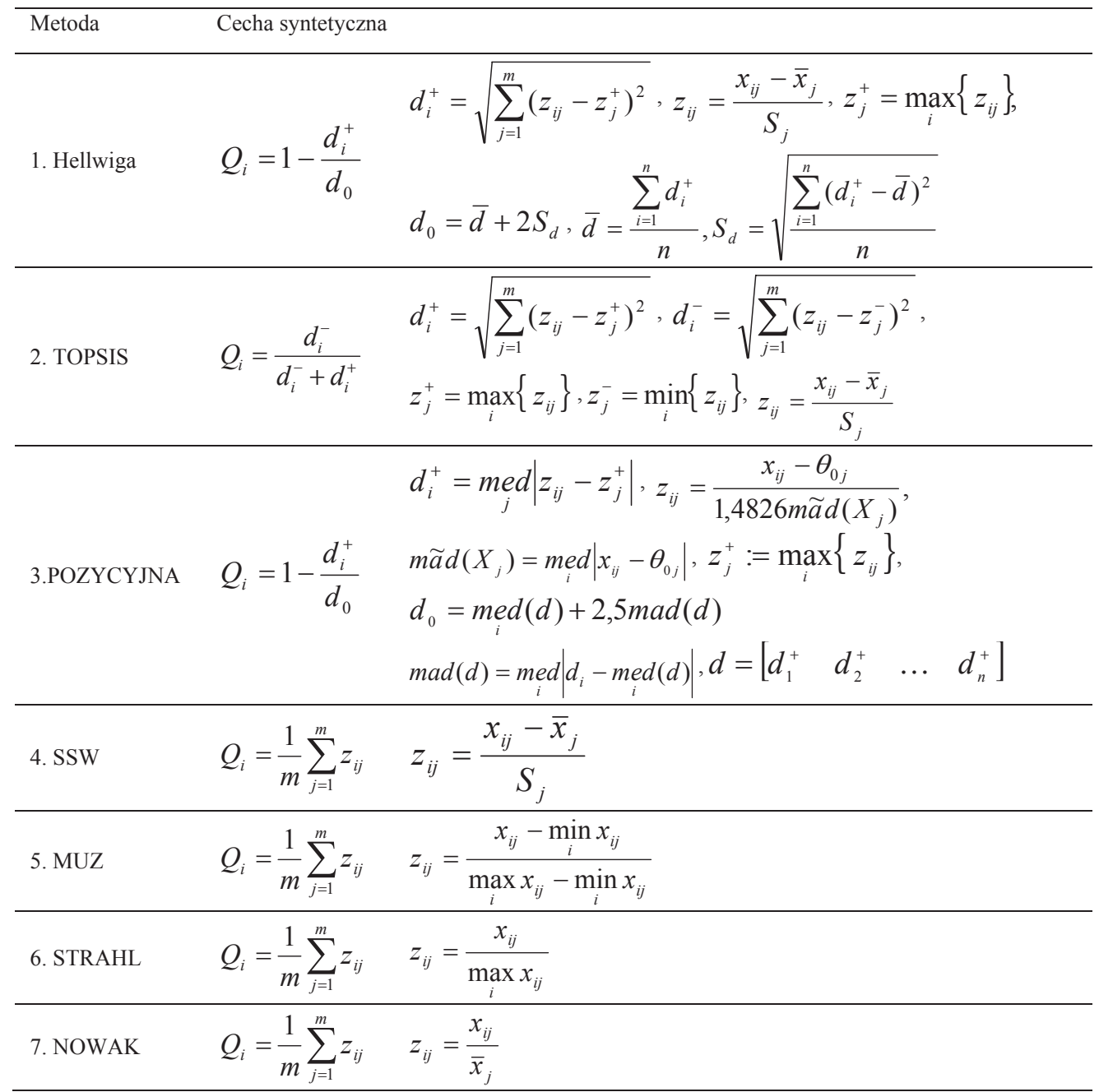

Źródło: opracowanie własne, gdzie: $x_{i j}$ - wartość $j$-tej cechy dla $i$-tego województwa; $z_{i j}$ - wartość

unormowana $j$-tej cechy dla $i$-tego obiektu; $\bar{x}_{j}, S_{j}$ to odpowiednio średnia arytmetyczna i odchylenie

standardowe j-tej cechy; $Q_{i}$ - wartość cechy syntetycznej dla $i$-tego obiektu; $\theta_{0 j}$ - wartość j-tej współrzędnej mediany Webera.

Następnie sporządzono na ich podstawie siedem rankingów badanych obiektów.

W drugim etapie analizy spośród sporządzonych rankingów (tym samym wykorzystanych metod) wybrano ten, który jest najbardziej podobny do pozostałych, czyli ten dla którego $\bar{u}_{p}$ jest największe (Kukuła, Luty 2015; 2017), gdy: 


$$
\bar{u}_{p}:=\frac{1}{v-1} \sum_{\substack{q=1 \\ p \neq q}}^{v} m_{p q}, \quad p, q=1,2, \ldots, v
$$

gdzie: $v$ - liczba rankingów; $m_{p q}=1-\frac{2 \sum_{i=1}^{n}\left|c_{i p}-c_{i q}\right|}{n^{2}-z}$ (Kukuła, 1989), takie, że: $c_{i p}, c_{i q}$ - odpowiednio pozycja i obiektu w rankingu o numerze $p, q ; z=\left\{\begin{array}{ll}0, & n \in P \\ 1, & n \notin P\end{array}\right.$, $P$ - zbiór liczb naturalnych parzystych; $m_{p q} \in[0,1]$.

Wybrana, w wyżej opisany sposób metoda stanowi podstawę do sporządzenia i interpretacji rankingu województw ze względu na gospodarkę odpadami komunalnymi w 2015 roku.

\section{Wyniki badań}

Dzięki zastosowaniu wymienionych metod $\mathrm{w}$ tabeli 3 , bazując na wytypowanym zestawie cech dokonano hierarchizacji województw według wartości syntetycznych mierników z wykorzystaniem siedmiu procedur porządkowania liniowego (rys. 1). Analizując wyniki prezentowane na rysunku 1 można zauważyć, że układy porządkowe różnią się. Jedynie dwa województwa mazowieckie i świętokrzyskie we wszystkich rozważanych wariantach nie zmieniały pozycji i były to odpowiednio miejsca pierwsze i ostatnie w rankingu.

Dla każdej pary przedstawionych układów porządkowych oszacowano wartość miary $m_{p q}$. Wszystkie wyliczone wartości $m_{p q}$ zapisano w macierzy $M$, w której numer wiersza (kolumny) odpowiada metodzie oznaczonej w tabeli 3.

$$
M=\left[\begin{array}{ccccccc}
1,000 & 0,875 & 0,797 & 0,922 & 0,922 & 0,922 & 0,875 \\
& 1,000 & 0,891 & 0,938 & 0,953 & 0,906 & 0,781 \\
& & 1,000 & 0,859 & 0,875 & 0,844 & 0,750 \\
& & & 1,000 & 0,984 & 0,953 & 0,828 \\
& & & & 1,000 & 0,938 & 0,828 \\
& & & & & 1,000 & 0,844 \\
& & & & & & 1,000
\end{array}\right]
$$


Wektor wartości miary podobieństwa $\left(\bar{u}_{p}\right)$, w którym numer kolumny odpowiada metodzie według porządku przedstawionego $\mathrm{w}$ tabeli 3 :

$$
\left\lfloor\bar{u}_{p}\right\rfloor=\left[\begin{array}{lllllll}
0,914 & 0,917 & 0,901 & 0,818 & 0,885 & 0,891 & 0,836
\end{array}\right] .
$$

W rozpatrywanym problemie ranking województw uzyskany na podstawie cechy syntetycznej wyznaczonej metodą MUZ jest najbliższy w stosunku do wszystkich pozostałych wyznaczonych rankingów $\left(\bar{u}_{p}=0,917\right)$.

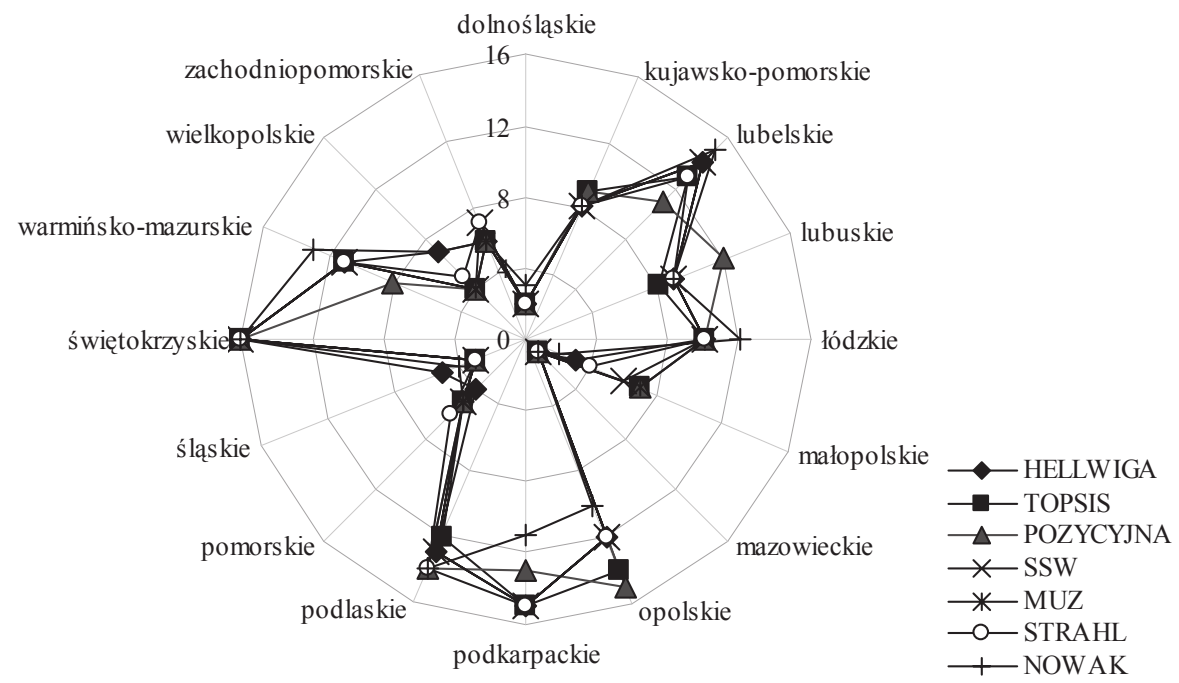

Rys. 1. Rangi województw według metod porządkowania liniowego przedstawionych w tabeli 3

Fig. 1. Ranks of voivodeships according to a linear ordering methods shown in table 3

Źródło: opracowanie własne na podstawie danych z tabeli 1.

Ranking polskich województw ze względu na gospodarkę odpadami komunalnymi w 2015 roku przedstawiono w tabeli 4. Ponadto, województwa zostały podzielone ze względu na poziom rozwoju gospodarowania odpadami na cztery grupy o poziomie:

- bardzo wysokim (grupa I): $Q_{i} \in\left(\max _{i} Q_{i}-0,25 R ; \max _{i} Q_{i}\right]$,

- wysokim (grupa II): $Q_{i} \in\left(\max _{i} Q_{i}-0,5 R ; \max _{i} Q_{i}-0,25 R\right]$,

- średnim (grupa III): $Q_{i} \in\left(\max _{i} Q_{i}-0,75 R ; \max _{i} Q_{i}-0,5 R\right]$,

- niskim (grupa IV): $Q_{i} \in\left[\min _{i} Q_{i} ; \max _{i} Q_{i}-0,75 R\right]$,

$\operatorname{gdzie} R=\max _{i} Q_{i}-\min _{i} Q_{i}$. 
Tabela 4. Ranking województw ze względu na wartości cechy syntetycznej wyznaczonej metodą MUZ z podziałem na grupy

Table 4. Ranking of the voivodeships due to value of synthetic variable designated by the Unitary Zero Method with division into groups

\begin{tabular}{lcc}
\hline Województwo & $Q_{i}$ & Grupa \\
\hline mazowieckie & 0,795 & I \\
\hline dolnośląskie & 0,567 & \\
śląskie & 0,488 & II \\
wielkopolskie & 0,456 & \\
pomorskie & 0,412 & \\
\hline zachodniopomorskie & 0,383 & \\
małopolskie & 0,380 & III \\
kujawsko-pomorskie & 0,313 & \\
lubuskie & 0,302 & \\
lódzkie & 0,283 & \\
warmińsko-mazurskie & 0,239 & IV \\
opolskie & 0,236 & \\
\hline podlaskie & 0,216 & \\
lubelskie & 0,206 & \\
podkarpackie & 0,160 & \\
świętokrzyskie & 0,047 & \\
\hline
\end{tabular}

Źródło: opracowanie własne na podstawie danych z tabeli 1.

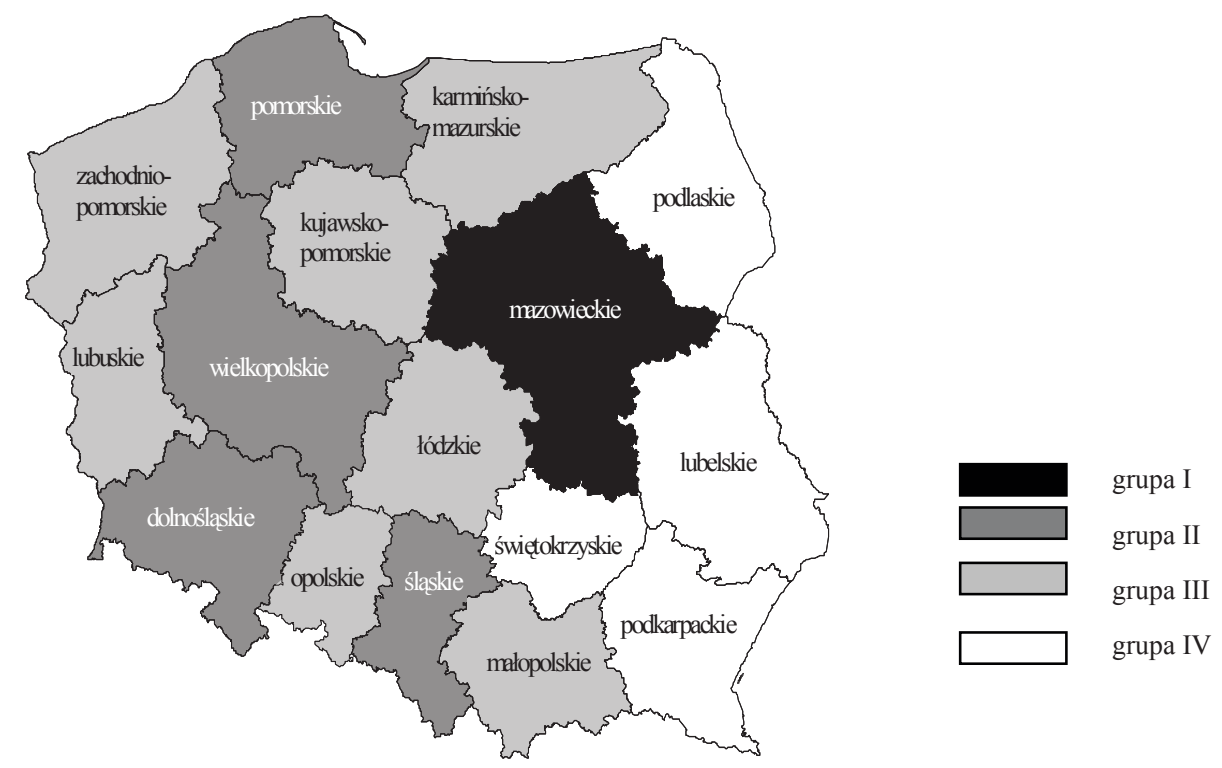

Rys. 2. Przestrzenne zróżnicowanie województw ze względu na poziom rozwoju gospodarki odpadami komunalnymi w 2015 roku

Fig. 2. Groups of similar voivodeships due to the waste management in the year 2015

Źródło: opracowanie własne na podstawie tabeli 4. 
Grupa I jest złożona z jednego obiektu. Jest nim województwo mazowieckie, które charakteryzuje się najwyższym poziomem rozwoju gospodarki komunalnej. Grupę o wysokim poziomie zjawiska tworzą cztery województwa, są to: dolnośląskie, śląskie, wielkopolskie, i pomorskie. Najliczniejszą grupę (III) tworzy aż siedem województw (zachodniopomorskie, małopolskie, kujawsko-pomorskie, lubuskie, łódzkie, warmińskomazurskie, opolskie). Wyróżniają się one średnim zaawansowaniem gospodarowania odpadami. Z kolei najsłabiej rozwinięty poziom wyróżnia województwa: podlaskie, lubuskie, podkarpackie i świętokrzyskie.

Podsumowując należy zauważyć, iż jakość gospodarowania odpadami komunalnymi jest znacząco regionalnie zróżnicowana. Świadczy o tym iloraz wartości skrajnych tej zmiennej syntetycznej na poziomie 16,8 .

\section{Podsumowanie}

1. Zastosowanie wielowymiarowej analizy statystycznej jest użytecznym narzędziem w badaniach regionalnych.

2. Budowa rankingu ze względu na poziom określonego zjawiska złożonego, przy wykorzystaniu aparatu badawczego wielowymiarowej analizy porównawczej wymaga dokonania wyboru: cech diagnostycznych oraz metody porządkowania liniowego.

3. Cechy typowane do opisu zjawiska złożonego winny posiadać walor ważności merytorycznej. Tu należy polegać na wiedzy analityka o mechanizmie zmian zjawiska złożonego. Ponadto, cechy zakwalifikowane do zbioru cech diagnostycznych winny spełniać warunek dostatecznej zmienności.

4. Wyniki badań wskazują że wybór metody porządkowania linowego rzutuje na ranking badanych obiektów. Zastosowana procedura stanowi, pomocne narzędzie wyboru metody porządkowania liniowego obiektów.

5. Prezentowany sposób wyboru metody porządkowania liniowego oparty na porównaniach międzyrankingowych charakteryzuje prostota konstrukcji oraz duże możliwości aplikacyjne w kwantytatywnych analizach regionalnych.

6. W ocenie poziomu rozwoju gospodarki odpadami komunalnymi ranking województw uzyskany na podstawie cechy syntetycznej wyznaczonej metodą MUZ jest najbliższy w stosunku do wszystkich pozostałych wyznaczonych rankingów.

7. Poziom rozwoju gospodarki odpadami nie rozkłada się równomiernie na poszczególne województwa. Istnieją ogromne różnice w tym zakresie między województwem przodującym w rankingu (mazowieckie) a pozostałymi województwami, w tym w szczególności województwem świętokrzyskim.

8. Województwa Polski charakteryzują się w znacznej większości co najwyżej średnim poziomem rozwoju gospodarki odpadami komunalnymi.

\section{Literatura}

Adamowicz, M. (2014). Europejska koncepcja biogospodarki i jej przełożenie na działania praktyczne (European concept of bioeconomy and its bearing on practical use). Studia Ekonomiczne i Regionalne, 7 (4), 5-21.

Bartosiewicz, S. (1976). Propozycja metody tworzenia zmiennych syntetycznych (Proposed method for creating synthetic variables.). Zeszyty Naukowe AE we Wroctawiu, 84, 5-7.

Borys, T. (1978). Metody normowania cech w statystycznych badaniach porównawczych (Methods of normalizing characteristics in statistical comparative studies). Przeglad Statystyczny, 2, 227-239. 
Grabiński, T. (1984). Wielowymiarowa analiza porównawcza w badaniach dynamiki zjawisk ekonomicznych (Multidimensional comparative analysis in the study of the dynamics of economic phenomena). Zeszyty Naukowe AE w Krakowie, Seria specjalna: Monografie, 61, Kraków.

Hellwig, Z. (1968). Zastosowanie metody taksonomicznej do typologicznego podziału krajów ze względu na poziom ich rozwoju oraz zasoby i strukturę wykwalifikowanych kadr (Application of the taxonomic method to the typological division of countries due to the level of their development and the resources and structure of qualified personnel). Przeglad Statystyczny, 4, 307-327.

Hwang, C.L., Yoon, K. (1981). Multiple Attribute Decision Making: Methods and Applications, Springer Verlag.

Kisielińska, J. (2016). Ranking państw UE ze względu na potencjalne możliwości zaspokojenia zapotrzebowania na produkty rolnicze $\mathrm{z}$ wykorzystaniem metod porządkowania liniowego (Ranking of EU countries due to the potential possibilities of meeting the demand for agricultural products using linear ordering methods). Problemy Rolnictwa Światowego, 16(3), 142-152.

Kukuła, K. (1989). Statystyczna analiza strukturalna i jej zastosowanie w sferze usług produkcyjnych dla rolnictwa (Statistical structural analysis and its application in the sphere of production services for agriculture). Zeszyty Naukowe AE w Krakowie, Seria specjalna: Monografie, 89, Kraków.

Kukuła, K. (2000). Metoda unitaryzacji zerowanej (The method of zero-standardization). PWN, Warszawa.

Kukuła, K., Luty, L. (2015). Propozycja procedury wspomagającej wybór metody porządkowania liniowego (Proposition of procedures supporting the choice of the method of linear ordering). Przeglad Statystyczny, 62(2), 219-231.

Kukuła, K. (2017). Zanieczyszczenia środowiska a działalność proekologiczna w Polsce w 2015 roku w świetle wielowymiarowej analizy porównawczej (Environmental Pollution and Pro-ecological Activity in Poland in 2015 in the Aspect of Multidimensional Comparative Analysis). Problemy Rolnictwa Światowego, 17(3), 226-238.

Kukuła, K., Luty, L. (2017). Jeszcze o procedurze wyboru metody porządkowania liniowego (Still about the procedure of choosing the method of linear ordering). Przeglad Statystyczny, 64(2), 163-176.

Lira, J., Wagner, W., Wysocki, F. (2002). Mediana w zagadnieniach porządkowania obiektów wielocechowych (Median in the problems of ordering multi-feature objects). W: Paradysz J. (red.), Statystyka regionalna w służbie samorządu lokalnego i biznesu, Internetowa Oficyna Wydawnicza Centrum Statystyki Regionalnej, AE, Poznań, 87-99.

Młodak, A. (2006). Analiza Taksonomiczna w statystyce regionalnej (Taxonomic analysis in regional statistics). Difin, Warszawa.

Nowak, E. (1977). Syntetyczne mierniki plonów w krajach europejskich (Synthetic measure of crops in European countries). Wiadomości Statystyczne, 10, 19-22.

Ochrona środowiska 2016 (Environment 2016). GUS, Warszawa, 333-337.

Panek, T. (2015). Analiza porównawcza subiektywnego dobrostanu w Europie (Comparative analysis of subjective animal welfare in Europe). Wiadomości Statystyczne, 2, 1-26.

Pawełek, B. (2008). Metody normalizacji zmiennych w badaniach porównawczych złożonych zjawisk ekonomicznych (Methods of normalization of variables in comparative studies of complex economic phenomena). Zeszyty Naukowe UE, Seria specjalna: Monografie, 187, Kraków.

Perkal, J. (1953). Taksonomia wrocławska (Wrocław's taxonomy). Przegląd Antropologiczny, t. 19, Polskie Towarzystwo Antropologiczne i Polskie Zakłady Antropologii, Poznań, 209-219.

Strahl, D. (1978). Propozycja konstrukcji miary syntetycznej (A proposal for the construction of a synthetic measure). Przeglad Statystyczny, 25(2), 205-215.

Walesiak, M. (2014). Przegląd formuł normalizacji wartości zmiennych oraz ich własności w statystycznej analizie wielowymiarowej (Review of formulas for normalization of the values of variables and their properties in statistical multidimensional analysis). Przegląd Statystyczny, nr 4, 363-372.

Wesołowski, W.J. (1975). Programowanie nowej techniki (Programming a new technique). PWN, Warszawa.

Do cytowania / For citation:

Kukuła K., Luty L. (2018). O wyborze metody porządkowania liniowego do oceny gospodarki odpadami w Polsce w ujęciu przestrzennym. Problemy Rolnictwa Światowego, 18(2), 183-192; DOI: $10.22630 /$ PRS.2018.18.2.46

Kukuła K., Luty L. (2018). On the Selection of the Linear Ordering Method for the Evaluation of Waste Management in Poland in Spatial Approach (in Polish). Problems of World Agriculture, 18(2),183-192; DOI: 10.22630/PRS.2018.18.2.46 